\title{
Children with Orofacial Clefts in School
}

\section{Miroslav Meier}

\begin{abstract}
The paper presents results of a research that dealt with the issue of acceptance of children with orofacial clefts in kindergarten and elementary schools from the point of view of parents of children with orofacial clefts. In addition, it was investigated what kind of support for education in the kindergarten and elementary school would be welcome by parents of children with orofacial clefts.
\end{abstract}

Key words: children, kindergarten, orofacial cleft, support, preschool age, parents, elementary schools.

\section{Děti s orofaciálními rozštěpy ve škole}

\section{Abstrakt}

Příspěvek přináší výsledky výzkumu, který se zabýval problematikou přijímání dětí s orofaciálními rozštěpy v mateřských a základních školách z pohledu rodičů dětí s orofaciálními rozštěpy. Dále bylo zjištováno, jakou podporu při edukaci v mateřské, resp. základní škole by rodiče dětí s orofaciálními rozštěpy přivítali.

Klíčová slova: děti, mateřské školy, orofaciální rozštěp, podpora, předškolní věk, rodiče, základní školy. 


\section{Introduction}

Children with various types of handicaps can be encountered more and more frequently not only in "special" schools but also in "normal" schools. The research presented in this text was focused on children with orofacial clefts in kindergartens and elementary schools. The research was carried out within the project of the Student Grant Competition of the Faculty of Science, Humanities and Education, Technical University of Liberec titled Children with Orofacial Clefts in Schools (SGS 21205). Despite increasingly better complex care provided to children with orofacial clefts in developed countries currently, some of these children have clearly visible differences or others not visible at first sight that may cause trouble when attending kindergartens or elementary schools. Visible differences include mainly scars in their faces and anomalies in their teeth. Invisible differences are caused by different life style of children with orofacial clefts to a great extent (in comparison with intact population). They spend much more time in various medical facilities where consequences of orofacial clefts are treated. This is not the only thing that can influence the development of these children's personalities. The particular extent and impact of the differences are naturally dependent on the type and degree of handicap, on personal as well as social specifics of each child.

\section{Definition of terms}

Orofacial clefts can be characterised as congenital developmental abnormalities affecting the hard parts dividing the oral and nasal cavities or the palatopharyngeal sphincter (Sovák in Lechta et al. 2003, p. 115). The logopedic dictionary says that cleft lips and cleft palates can be typical or atypical. Typical clefts can be one-sided or two-sided and of various degree - from microclefts through mild, incomplete or complete. Clefts may appear in: lip, jaw, hard palate, soft palate. There can also be various combinations e.g. cleft soft palate and lip. Atypical clefts are so-called macrostomies, cleft lower lip etc. Further, there are cleft palatine uvulas and cleft tongues (Dvořák 1998, pp. 146, 147), (Škodová, Jedlička et al. 2007, p. 230).

Cleft palates are a developmental defect - i.e. they are results of organs not joining during the intrauterine development of human face parts. Causes of orofacial clefts have not been clarified completely so far; they are related to internal as well as external factors (Škodová, Jedlička et al. 2007, pp. 218, 226). Despite this fact, the causes of orofacial clefts identified most frequently are the influence of harmful substances in the first trimester of pregnancy, fetus developmental disorders and heredity (Vrbová et al. 2015, p. 16).

Palatolalia, a speech sound disorder, can be found in children with orofacial clefts. Speech sound disorders are one of the types of distorted communication ability. Palato- 
lalia is characterised by resonance changes (open mumbling) and distorted articulation. Children with palatolalia frequently have retarded speech development. Disorders of facial expression, intake, swallowing and breathing can be present in them; further anomaly of jaws and teeth, hearing impairments (Vrbová et al. 2015, p. 16). Palatolalia is induced by non-operated orofacial cleft, or when sufficient palatopharyngeal sphincter has not been formed (Jehličková 2015, p. 20).

The prognosis of children with orofacial clefts depends not only on the type and severity of their orofacial cleft but also on the fact whether there is another handicap (e.g. sensual, mental) present in the particular child. Vohradník (in Škodová, Jedlička et al. 2007, p. 251) mentions that people with orofacial clefts enter into marriage less frequently but achieve a higher level of education. Children with orofacial clefts achieve worse results in socialisation tests and are less assertive. Psychological help is more frequently sought by those who suffer, besides the orofacial cleft, from communication disorder, or those who have feelings of inferiority.

This part of the text can be concluded with a statement that people with orofacial clefts can meet specialists from the fields of surgery, dentistry, communication, social psychology etc. when solving their problems throughout their lives, depending on the type and severity of their handicap. This is why both people with orofacial clefts and their families should be active and equal partners for the mentioned specialists. The best results can be expected then (Lechta, et al. 2005, p. 85).

\section{Research design, research sample}

Beside other things, the research was motivated by a student of the blended form of study at our department who is a mother to a child with orofacial cleft. Problems and troubles encountered in care of her child so far led her to the decision to write her diploma thesis on Children with Orofacial Clefts. She deals, among others, with otherness of children with orofacial clefts and its influence on acceptance of these children by school mates. This student participated in obtaining necessary data for the research described here. The following research objectives were formulated on the basis of consultations with the student and her contacts with the community of parents to children with orofacial clefts:

- To find whether school mates more frequently accept boys with orofacial clefts than girls with orofacial clefts.

- To find whether school mates more frequently accept preschool children than school children with orofacial clefts.

- To find what parents of children with orofacial clefts consider being the hardest issue of these children's kindergarten or elementary school attendance. 
- To find what parents of children with orofacial clefts consider being the hardest issue in these children's "common" - out-of-school life.

- To find whether parents of children with orofacial clefts would welcome some support - "in general" and in relation to school attendance - and of what kind.

- To find on what support for children with orofacial clefts in kindergardens or elementary schools should be focused.

Fulfilment of the said research objectives could improve the situation of children with orofacial clefts and make the situation of their parents easier.

Data necessary for fulfilment of the research objectives were obtained by means of an anonymous online questionnaire designed for parents of children of children with orofacial clefts. The questionnaire consisted of 39 items. These were closed, semiclosed and open questions.

The research sample was 55 parents of children with orofacial clefts - while there was a condition that the children attend kindergarden or elementary school. There were 47 women and 8 men among the respondents. The most represented age group was that of respondents aged 36 to 45 years of age $(54.5 \%)$, followed by respondents of 36 to 35 years of age $(30.9 \%)$, the least represented group was respondents aged 46 to 55 years of age (14.5\%). There was the majority of university educated respondents $(56.4 \%)$, followed by respondents with secondary education with school-leaving exam (32.7\%); the remaining respondents had secondary education without school-leaving exam ( $7.3 \%)$ and higher vocational education (3.6\%). Kindergarten was attended by 28 children, elementary school by 27 children.

\section{Research results}

With regard to the amount of obtained data and the space at our disposal, our presentation will be limited to data related to the research objectives.

Objective 1: To find whether school mates more frequently accept boys with orofacial clefts than girls with orofacial clefts.

There were 36 (65.5\%) boys and 19 (34.5\%) girls among the children with orofacial clefts. Details on accepting or non-accepting of children with orofacial clefts in school can be found in Chart 1 - it is evident that there are only minimal differences between accepting boys and girls in school. 


\section{Chart 1}

Acceptance of children with orofacial clefts in school

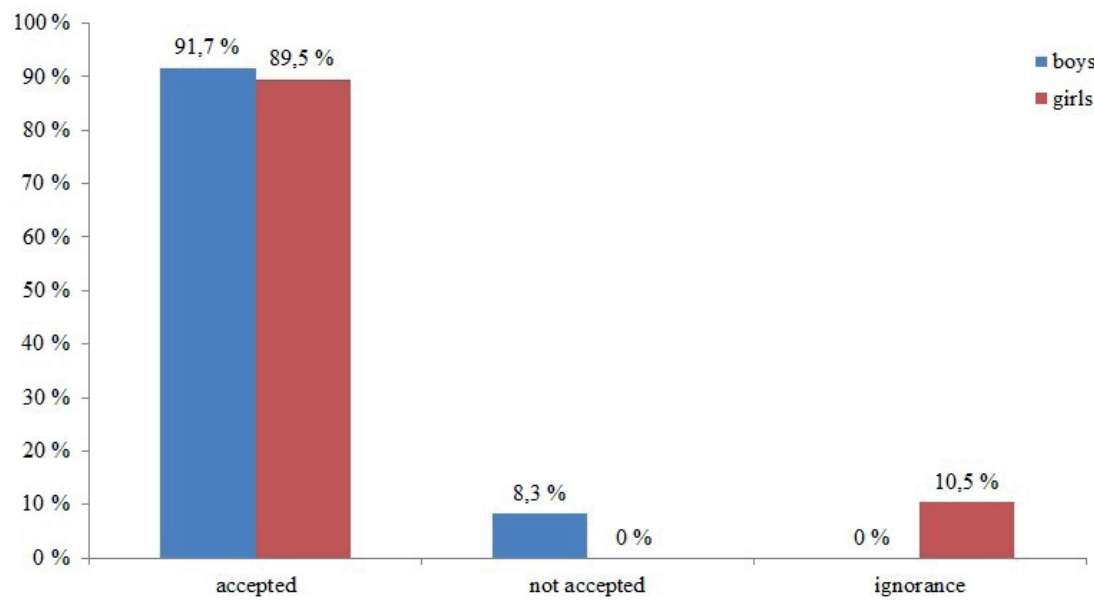

Despite this, chi-square for contingency table was tested by means of the test of independence in order to find whether the observed differences are statistically sifnificant. The test criterion chi-square was calculated under the critical value mentioned in statistical tables (the significance level used here and below was 0.05). It was confirmed that there are no statistically significant differences in accepting girls and boys with orofacial clefts. It was assumed that consequences of orofacial clefts will have a greater influence in girls than in boys. This thesis was not confirmed - what can be understood as positive. Acceptance of boys and girls is similar.

Objective 2: To find whether school mates more frequently accept preschool age children than school age children with orofacial clefts.

$25 \%$ of the respondents stated that acceptance of children with orofacial clefts was more difficult in preschool age; on the contrary, $75 \%$ of the respondents expressed their opinion that acceptance was more difficult in school age. The difference in accepting children with orofacial clefts in preschool and school age is considerable. The goodness of fit test chi-square was used for evaluation of the question whether the differences are statistically significant. It was found that the differences are statistically significant. The finding can be a result of e.g. the fact that kindergarten teachers have more intense and frequent contact with children in comparison with elementary school teachers, and thus they can control children more and influence children's undesired manifestations more strongly. 
Objective 3: To find what parents of children with orofacial clefts consider being the hardest issue of these children's kindergarten or elementary school attendance. This objective was to show what issues should be targeted when working with families of children with orofacial clefts.

\section{Chart 2}

What are the hardest issues in school attendance

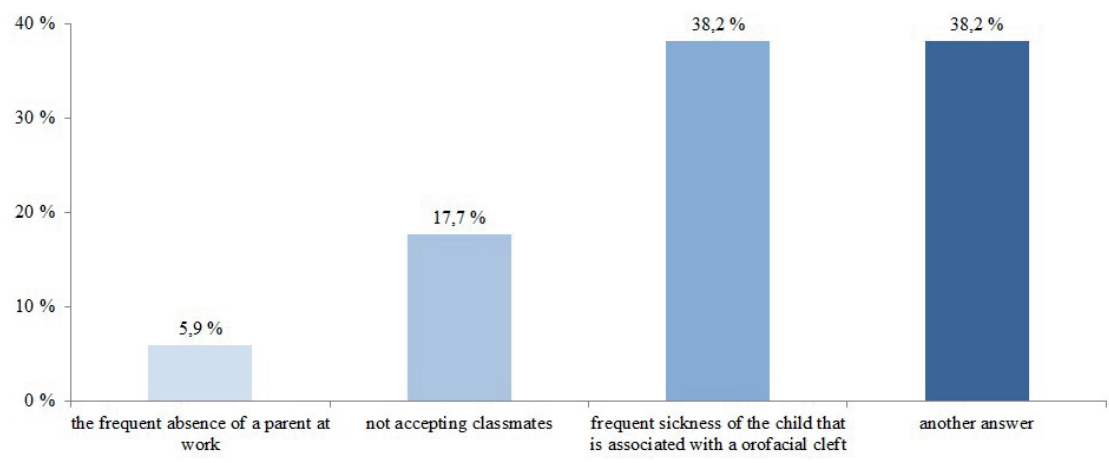

The respondents reported high sickness rate of children with orofacial clefts (38.2 \%) and non-acceptance by school mates (17.7\%) as the most difficult problems; significantly less parents' absence from work (5.9\%) - see Chart 2. Other answers (38.2 \% in total) included e.g.: ADHD, lax approach of teachers in school. The above facts imply that what should be taken into consideration when educating children with orofacial clefts is especially consequences of the high sickness rate in these children and related problems.

Objective 4: To find what parents of children with orofacial clefts consider being the hardest issue in these children's "common" - out-of-school life.

The respondents reported quite a wide range of various "troublesome" fields. Worse communication, the children's distorted communication ability were mentioned at the first two positions by a wide margin. These were closely followed by time demands etc. related to medical therapies and medical examinations and check-ups and the induced lack of time for common activities with children (playing, etc.), need to explain the necessity of medical interventions and check-ups to the children. The third position was taken by integration into peer groups. This was followed by improper looks, reactions and offensive questions of the intact part of population; together with speech therapy of poor quality and high sickness rate. 
The above mentioned findings show clearly that the greatest attention should be paid to communication skills in children with orofacial clefts. Further formulation of e.g. recommendations considering explanation of the need of medical interventions to the children with orofacial clefts. It is not possible to omit the intact part of population either who should be informed of people with handicaps - including children with orofacial clefts - in an adequate way. The intact population's reactions, approach could be better then.

\section{Objective 5: To find whether parents of children with orofacial clefts would welcome} some support - "in general" and in relation to school attendance - and of what kind. Specific support would be welcome by $58 \%$ of the parents of children with orofacial clefts (the opposite opinion was expressed by $42 \%$ of the parents). Such support in common - out-of-school life should be focused mainly on better information of orofacial clefts (including better information provided right in maternity hospitals and better information for outpatient physicians) according to the respondents. Activities in organizations and groups of parents of children with orofacial clefts were mentioned as frequently as above-mentioned information was. Speech therapy of good quality followed closely. Further financial support - e.g. for drugs necessary for children with orofacial clefts, nasal shells, scar creams, tooth implants, dental braces.

According to the respondents, support during kindergarten attendance should be focused mainly on better information for kindergarten teachers; closely further on adequate information for intact school mates and their paretns and on speech therapy. What was further mentioned were assistant teachers, psychological support, a smaller number of mirrors in kindergarten buildings etc.

According to the respondents, support during elementary school attendance should be focus above all on information for intact school mates and their parents and on assistant teachers (both mentioned with the same frequency). The following was mentioned by a wide margin: speech therapy, better information for teachers, better surveillance during breaks, greater interest - involvement of teachers, school psychologist etc.

Most parents of children with orofacial clefts would welcome such support. They very often mentioned information for both laid public (what is relatively understandable) as well as specialists (physicians, teachers) - this is less understandable, and it should be an appeal to educators training these specialists. Better information for laid public is a task for a wide range of experts (for all pedagogues, educators in the really broad sense of the word). This confirmed what is mentioned about families with other types of handicaps, namely that communication, information, cooperation within "community" - within organizations, groups of parents of children with a similar type of handicap - are considered very important for parents of these children. 
Objective 6: To find on what support for children with orofacial clefts in kindergartens or elementary schools should be focused.

Support for children with orofacial clefts in kindergartens should be focused mainly on speech therapy. It is followed by a wide margine by: beter information for intact school mates and their parents, suitable group supervision not emphasizing differences among children (inclusion into the group, communication), instruction of teachers, psychological and social support for children with orofacial clefts and emphasis on spiritual values (not to evaluate only "with one's eyes"), frequently missed classes, fine motor schills, assistent teachers.

Support for these children in elementary schools should focus mainly on formation of groups without emphasizing differences among children (prevention of bullying). The following was mentioned with equal frequency: instruction of teachers, adequate information for intact school mates and their parents, speech therapy. These were followed by a call for kinder teachers and their balanced evaluation of their children and psychological support.

Speech therapy was clearly preferred in kindergartens - what is understandable with regard to the developmental specifics of preschool children. It is desirable to have speech therapy of good quality what was frequently emphasized by the respondents. Another fundamental issue in both kindergarten and elementary schools is information for intact school mates and their parents and related formation of groups without emphasizing differences among children. This is a task for teachers who should provide adequate information of specifics of children with orofacial clefts to intact school mates and their parents and take care of ensuring the minimum of inopportune phenomena in groups in kindergartens and elementary schools.

\section{Conclusion}

Children with orofacial clefts form a relatively specific as well as internally differentiated part of the children's population. Excessive attention is usually not paid to them - people with other types of handicaps, disadvantages are usually covered by the media. However, this does not mean that children with orofacial clefts and their parents do not face a number of problems. The above described research was to find how children with orofacial clefts are accepted by their school mates in kindergartens and elementary schools; what is considered most difficult by their parents in their "common" as well as "school" life and what should be targeted by support for these children in kindergartens and elementary schools etc. (for details see the project objectives).

It was found out that there is no statistically significant difference between accepting boys and girls with orofacial clefts. On the contrary, there are statistically significant differences in acceptance of children with orofacial clefts by school mates in kinder- 
gartens and elementary schools - acceptance by school mates is definitively more difficult in elementary schools. The most difficult features when attending kindergartens or elementary schools are the high sickness rate in children with orofacial clefts and non-acceptance by school mates by a wide margin. In common life, the respondents identified poorer communication - distorted communication skills in children with orofacial clefts, and time demands of medical inverventions and check-ups by a wide margin. Most parents of children with orofacial clefts would welcome specific support focused on their children. Such support should be mainly: better information of orofacial clefts (for physicians, teachers, intact school mates and their parents); activities of organizations and groups of parents of children with orofacial clefts; speech therapy and appropriate choice of groups of children in schools.

We, trainers of teachers, should find indications in the stated findings how to shift our work further, update and change it. The prevailing majority of children with orofacial clefts is educated in "common" schools (with exception of children with more serious handicap) - thus, teachers, usually without complex special pedagogical qualification, encounter them. This is why it is desirable to educate future teachers (as well as current ones in the best case) in such a way that they are adequately prepared for educative work with children with orofacial clefts, for specifics brought by working with these children.

\section{References}

Dvořák, J. (1998). Logopedický slovník. $1^{\text {st }}$ ed. Ždár nad Sázavou: Logopedické centrum.

Jehličková, J. (2015). Metodika práce asistenta pedagoga podpora rozvoje počátečního čtení a psaní u žáků s narušenou komunikační schopností [online]. $1^{\text {st }}$ ed. Olomouc: UPOL. [cit. 16. 11. 2017]. ISBN 978-80-244-4713-1. Retrieved from: http://inkluze.upol.cz/ebooks/metodika-prurez-06/ metodika-prurez-06.pdf

Lechta, V., et al. (2003). Diagnostika narušené komunikační schopnosti. $1^{\text {st }}$ ed. Praha: Portál. ISBN 80-7178-801-5.

Lechta, V., et al. (2005). Terapie narušené komunikační schopnosti. $1^{\text {st }}$ ed. Praha: Portál. ISBN 80-7178-961-5.

Škodová, E., Jedlička, I., et al. (2007). Klinická logopedie. $2^{\text {nd }}$ revised ed. Praha: Portál. ISBN 978-80-7367-340-6.

Vrbová, R., et al. (2015). Katalog podpưrných opatření dílči část pro žáky s potřebou podpory ve vzdèlávání z důvodu narušené komunikační schopnosti [online]. $1^{\text {st }}$ ed. Olomouc: UPOL. [cit. 16. 11. 2017]. ISBN 978-80-244-4676-9. Retrieved from: http://inkluze.upol.cz/ebooks/katalog-nks/ katalog-nks.pdf 


\section{Contact:}

Mgr. Miroslav Meier, Ph.D.

Department of Social Studies and Special Pedagogy

Faculty of Science, Humanities and Pedagogy, Technical University of Liberec

Studentská 2, 46117 Liberec, Czech Republic

E-mail: miroslav.meier@tul.cz

Mgr. Miroslav Meier, Ph.D. - after graduating from the Faculty of Pedagogy of the Palacky University in Olomouc, Special Education - Teaching of Technical and Information Education (2005) and Doctoral Studies in Pedagogy (2008), he joined the Department of Social Studies and Special Education at the Faculty of Sciences, Humanities and Education Technical University in Liberec, where he works until now. It deals, among other things, with somatopedy, speech therapy, the use of information and communication technologies in people with different types of disability and school integration. 